University of Nebraska - Lincoln

DigitalCommons@University of Nebraska - Lincoln

Faculty Publications from the Harold W. Manter Laboratory of Parasitology

$1-1959$

Notes on the Prevalence of Hydatid Disease in Alaskan Moose

Robert L. Rausch

University of Washington, rausch@uw.edu

Follow this and additional works at: https://digitalcommons.unl.edu/parasitologyfacpubs

Part of the Parasitology Commons

Rausch, Robert L., "Notes on the Prevalence of Hydatid Disease in Alaskan Moose" (1959). Faculty Publications from the Harold W. Manter Laboratory of Parasitology. 395.

https://digitalcommons.unl.edu/parasitologyfacpubs/395

This Article is brought to you for free and open access by the Parasitology, Harold W. Manter Laboratory of at DigitalCommons@University of Nebraska - Lincoln. It has been accepted for inclusion in Faculty Publications from the Harold W. Manter Laboratory of Parasitology by an authorized administrator of DigitalCommons@University of Nebraska - Lincoln. 


\title{
NOTES ON THE PREVALENCE OF HYDATID DISEASE IN ALASKAN MOOSE
}

\author{
Robert A. Rausch
}

\author{
U.S. Fish and Wildlife Service, Box 6123, Anchorage, Alaska
}

In conjunction with current moose-management studies in south-central Alaska, ${ }^{1} 124$ pairs of lungs of moose (Alces alces) have been collected and examined for the presence of hydatid cysts, the larval stage of the cestode, Echinococcus granulosus. The lungs were collected in the Cook Inlet region between January 1, 1956 and January 1, 1958, mostly from animals accidentally killed by trains or cars.

The presence or absence of the tapeworm cyst was determined by visual inspection, palpation, and finally by sectioning the lungs into slices approximately $1 / 2$ in. thick. Hydatid larvae do not always localize in the lungs of the host; however, examination of 86 moose livers and hearts has given negative results. The lungs of 17 of the above animals were infected.

The life cycle of this parasite has been reviewed by R. L. Rausch (1952). The cycle usually involves ungulates as the intermediate host, and canids as the final host. The larval form, the hydatid cyst, is found in the intermediate hostusually moose and caribou (Rangifer arcticus) in this portion of Alaska. The adult tapeworm, in Alaska, is found in wolves (Canis lupus) or dogs (C. familiaris). Although coyotes (C. latrans) are possible final hosts, R. L. Rausch (viva voce) reports that the tapeworm has not been identified from coyotes inhabiting the study area.

In compiling the data, a natural geographic feature was used to divide the area into two parts (Tables 1 and 2). All moose collected north of the Knik Arm of Cook Inlet were considered to be in the Railbelt-Matanuska Valley populations, and all moose south of Knik Arm were considered to be in the Anchorage-Upper Kenai populations. In all probability there is very little, if any, interchange between these two areas, as Knik Arm and the adjoining Chugach Mountains constitute a formidable natural barrier.

The age classification of the moose listed in Tables 1 and 2 was determined by using the technique described by Skuncke (1949). This technique is largely based upon comparative wear of the mandibular teeth and distinguishes nine age classifications beyond Age Class Calf. Only Age Class I corresponds to the chronological age of the

${ }^{1}$ Undertaken with Federal Aid to Wildlife Restoration funds under Pittman-Robertson Project No. W3R, Alaska.

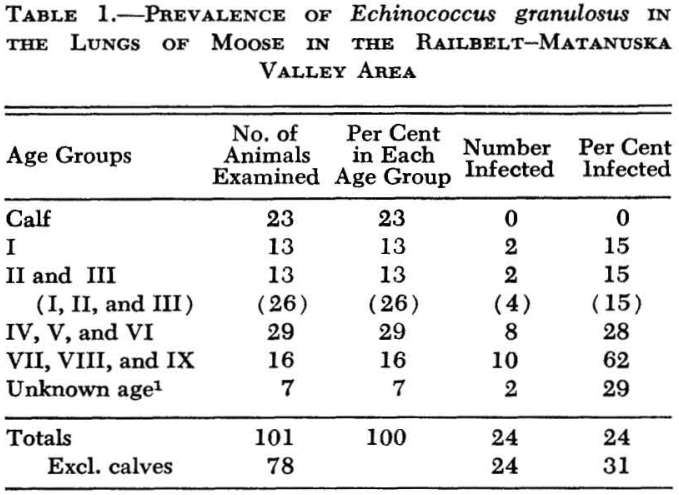

1 Age Class II and above.

individual. Considerable overlap occurs in the remaining eight age classes, which include moose from 2 to at least 20 years of age.

The prevalence of $E$. granulosus in a moose population seems dependent upon the availability of the parasite to the potential host and the length of time the animal has been exposed to it, i.e., the age of the individual. Although the present techniques of age determination are general, the correlation between the incidence of infection and the age of the animal is apparent.

E. granulosus is not common in moose populations located in the areas south of the Knik Arm. Only one instance of infection was observed in the 23 sets of lungs examined. The reasons for the differential prevalence of infection between the two areas are not fully understood at present. In fact,

Table 2.-Prevalence of Echinococcus granulosus in the Lungs of Moose in the Anchorage-Upper Kenai Area

\begin{tabular}{lcccc}
\hline \hline Age Groups & $\begin{array}{c}\text { No. of } \\
\text { Animals } \\
\text { Examined }\end{array}$ & $\begin{array}{c}\text { Per Cent } \\
\text { in Each } \\
\text { Age Group }\end{array}$ & $\begin{array}{c}\text { Number } \\
\text { Infected }\end{array}$ & $\begin{array}{c}\text { Per Cent } \\
\text { Infected }\end{array}$ \\
\hline Calf & 3 & 13 & 0 & 0 \\
I & 3 & 13 & 0 & 0 \\
II and III & 4 & 17 & 0 & 0 \\
$\quad$ (I, II, and III) & $(7)$ & $(30)$ & $(0)$ & $(0)$ \\
IV, V, and VI & 5 & 22 & 1 & 20 \\
VII, VIII, and IX & 8 & 35 & 0 & 0 \\
\hline Totals & 23 & 100 & 1 & 4 \\
$\quad$ Excl. calves & 20 & & 1 & 5 \\
\hline
\end{tabular}


the final host group is not definitely known for either study area. Wolves are absent or very rare in both areas; coyotes are present in both areas but are not abundant, and the mature tapeworm has not been identified from coyotes inhabiting the study areas. Dogs are very numerous in both areas and are allowed to roam freely by most owners. Quantitative information on the incidence of $E$. granulosus in dogs of these areas is not available, but in view of their abundance and distribution, dogs would seem to be logical final hosts.

Several authorities have discussed the possible pathogenic effects of hydatid disease on the ungulate host. Cowan (1948) indicated that hydatid disease reduces the vitality of the ungulate host to a marked degree. R. L. Rausch (op. cit.) stated that the disease appears to be essentially nonpathogenic in the natural mammalian hosts that have been reported for this cestode.

During this study, the general physical condition of each animal examined was recorded, and the incidence of pregnancies was also noted. In no instance was the physical condition of infected animals visibly different from that of noninfected animals, and the pregnancy rates of infected and noninfected animals were identical; 90 per cent of all females in Age Class II and above were pregnant. At present, the writer has observed no instances where hydatid disease appeared, upon gross examination, to be detrimental to the vitality of the ungulate host.

\section{Literature Cited}

Cowan, I. MCT. 1948. The occurrence of the granular tapeworm Echinococcus granulosus in wild game in North America. J. Wildl. Mgmt., 12(1):105-106.

Rauscr, R. L. 1952. Hydatid disease in boreal regions. Arctic, 5(3): 157-174.

SkUNCKE, F. 1949. Algen, studier, jakt och vård. Stockholm:P. A. Norstedt and Söners. 400pp.

Received for publication May 23, 1958. 